\title{
Mass balance measurements on glaciers in South Greenland
}

\section{Poul Clement}

During the 1982 field season mass balance measurements were carried out on three glaciers in South Greenland, Nordbogletscher and Valhaltindegletscher in the Johan Dahl Land area $25 \mathrm{~km}$ north of Narssarssuaq, and Narssaq Bræ $10 \mathrm{~km}$ north-west of Narssaq. The investigations are part of the GGU programme for regional mapping of the hydropower potential and also include observations on glacier dynamics, ice-dammed lakes and climateablation relationships.

\section{Mass balance of Nordbogletscher 1981/82}

The Nordbogletscher, an outlet from the Inland Ice (fig. 47) with an area of approximately $208 \mathrm{~km}^{2}$, is the main water source inside the Nordbosø basin $\left(308 \mathrm{~km}^{2}\right)$ which has been proposed as a reservoir for a hydroelectric project by the Greenland Technical Organization (GTO, 1980). Glaciological work in the area has been undertaken by the GGU since 1977.

On Nordbogletscher the winter balance for 1981/82 was measured at the end of May 1982 in snowpits and by depth sounding at stakes scattered over the whole glacier area (fig. 48). All the stakes from the previous year were found. The mean density in 11 snowpits from the front of the glacier ( $660 \mathrm{~m}$ above sea level) to the top of the accumulation area $(2100 \mathrm{~m}$ above sea level) was very uniform and found to be $0.40 \mathrm{~g} / \mathrm{cm}^{3}$. The winter balance gave a rather low value reflecting the relatively small amount of winter precipitation in South Greenland this year. The total winter balance was calculated to be 59.7 million $\mathrm{m}^{3}$, i.e. a specific value of only $0.29 \mathrm{~m}$ of water equivalent.

The summer balance on Nordbogletscher was determined at the 38 stakes at the beginning of September. At that time $20-40 \mathrm{~cm}$ of new snow already covered the whole glacier area; the new snow, however, has to be taken into next year's budget and is subtracted from the summer balance. The summer balance shows a marked increase with elevation (fig. 49), from $-3 \mathrm{~m}$ of water equivalent near the glacier terminus to zero at an elevation of $1800 \mathrm{~m}$.

A $19 \mathrm{~m}$ deep firn core taken on Nordbogletscher at an elevation of $2060 \mathrm{~m}$ shows that melting does occur at this elevation but the meltwater is retained within the firn and the area has no runoff (Braithwaite et al., 1982). In determining the summer balance on Nordbogletscher above the equilibrium line, snow densities have to be taken to a considerable depth in order to estimate the amount of refreezing in the deeper layers. Because of logistic problems, only the densities of the remaining winter snow were measured in September and the amount of refreezing in deeper layers is unknown. The summer balance above the equilibrium line (fig. 49) is thus probably a little too high.

However, using the results obtained, the total summer balance is calculated to be $-\mathbf{1 1 8 . 6}$ million $\mathrm{m}^{3}$ which corresponds to a mean specific value of $-0.57 \mathrm{~m}$ of water equivalent. The mass balance for the budget year 1981/82 thus shows a deficit of -58.9 million $\mathrm{m}^{3}$ or on average over the whole glacier area of $-0.28 \mathrm{~m}$ of water equivalent. The equilibrium line was close to $1600 \mathrm{~m}$ above sea level. 


\section{Mass balance problems on Nordbogletscher}

According to international guidelines, mass balance measurements should take place on glaciers inside well-defined hydrological basins where good maps are available and where results can be checked with discharge measurements (UNESCO, 1970). These assumptions cannot be satisfied in the case of Nordbogletscher. The area of Nordbogletscher is problematic as the glacier is part of the Inland Ice. The glacier map in figure 48 is drawn with respect to glaciological principles and surface topography.

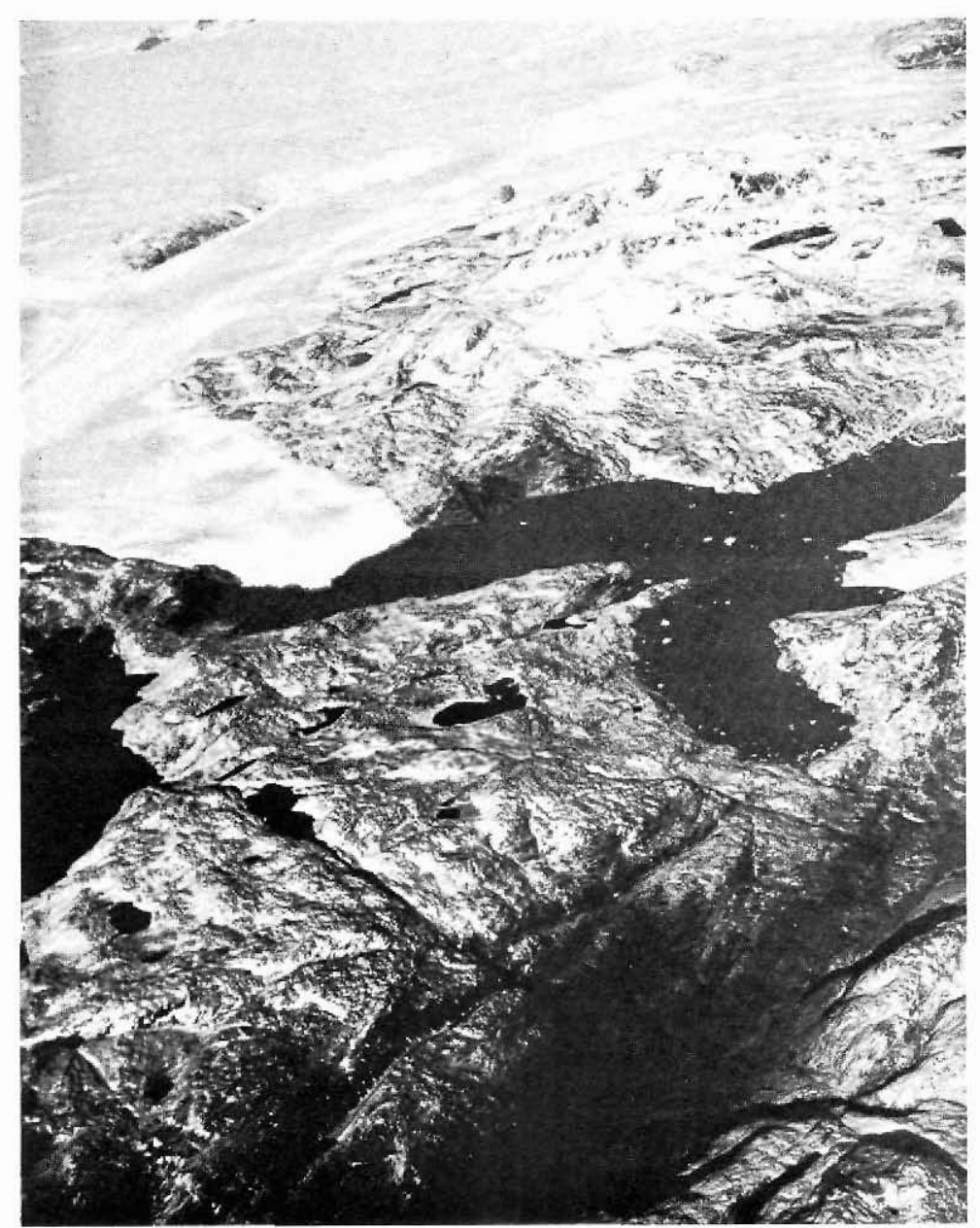

Fig. 47. Aerial view of Johan Dahl Land and the Nordbosø basin. The lake in the foreground is Nordbosø ( $660 \mathrm{~m}$ above sea level) which should act as a reservoir in the proposed hydropower project. Nordbogletscher, an outlet from the Inland Ice in the background, terminates in the lake and is the main water source as it occupies 68 per cent of the basin area. Photograph taken by Jan Andsbjerg in October 1978. 


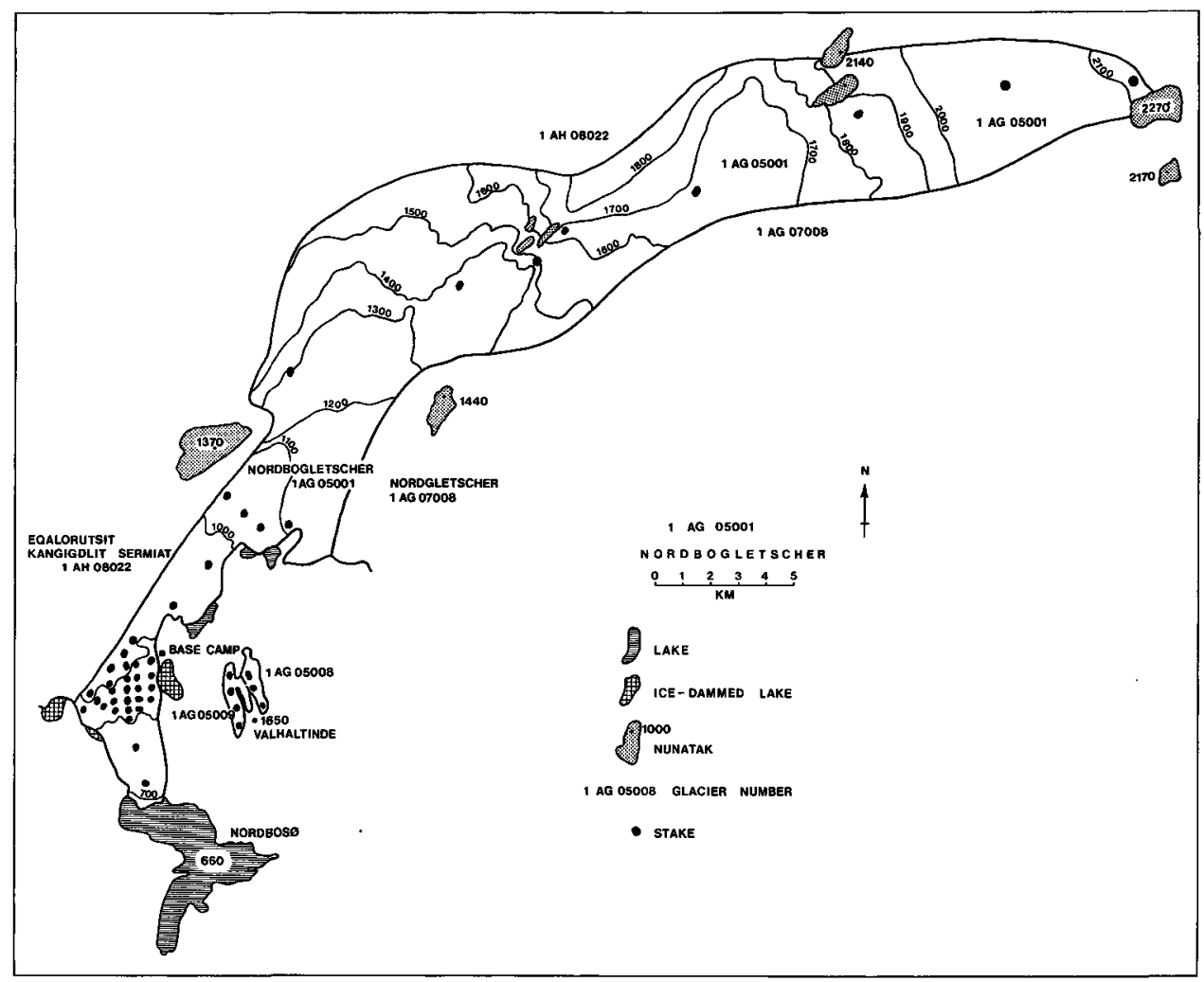

Fig. 48. Map of Nordbogletscher showing positions of the inserted stakes. The local glacier at Valhaltinde is also shown.

Comparing the mass balance results with the measured runoff from Nordbosø measured by the Greenland Technical Organization (GTO, 1982), one finds the results do not agree; in fact the summer balance from Nordbogletscher exceeds the annual runoff. The discrepancy is thought to be due to the problem of delineation between the topographic area of the glacier and the hydrological area. The topography of Johan Dahl Land is rather alpine and a lot of nunataks penetrate the Inland Ice. Thresholds at the glacier bed between the nunataks can divert meltwater into other areas independent of the surface slope. Furthermore, internal water channels do not have to follow the ice stream direction, i.e. water from the higher elevations of Nordbogletscher can go to either Eqalorutsit kangigdlit sermiat or Nordgletscher (fig. 48) and thus not reach the outlet stream of Nordbosø. The results thus indicate that a splitting up of the Inland Ice into individual sectors is artificial and of little use in glacier-hydrological studies.

In order to solve the problem, a glacier-hydrological map has to be produced. The bed topography can be determined by means of radio-echo sounding. In September 1982 the GGU undertook a radio-echo programme in cooperation with the Electromagnetic Institute of the Technical University of Denmark (Søren Overgaard and Jens Maaløe). About $200 \mathrm{~km}$ 


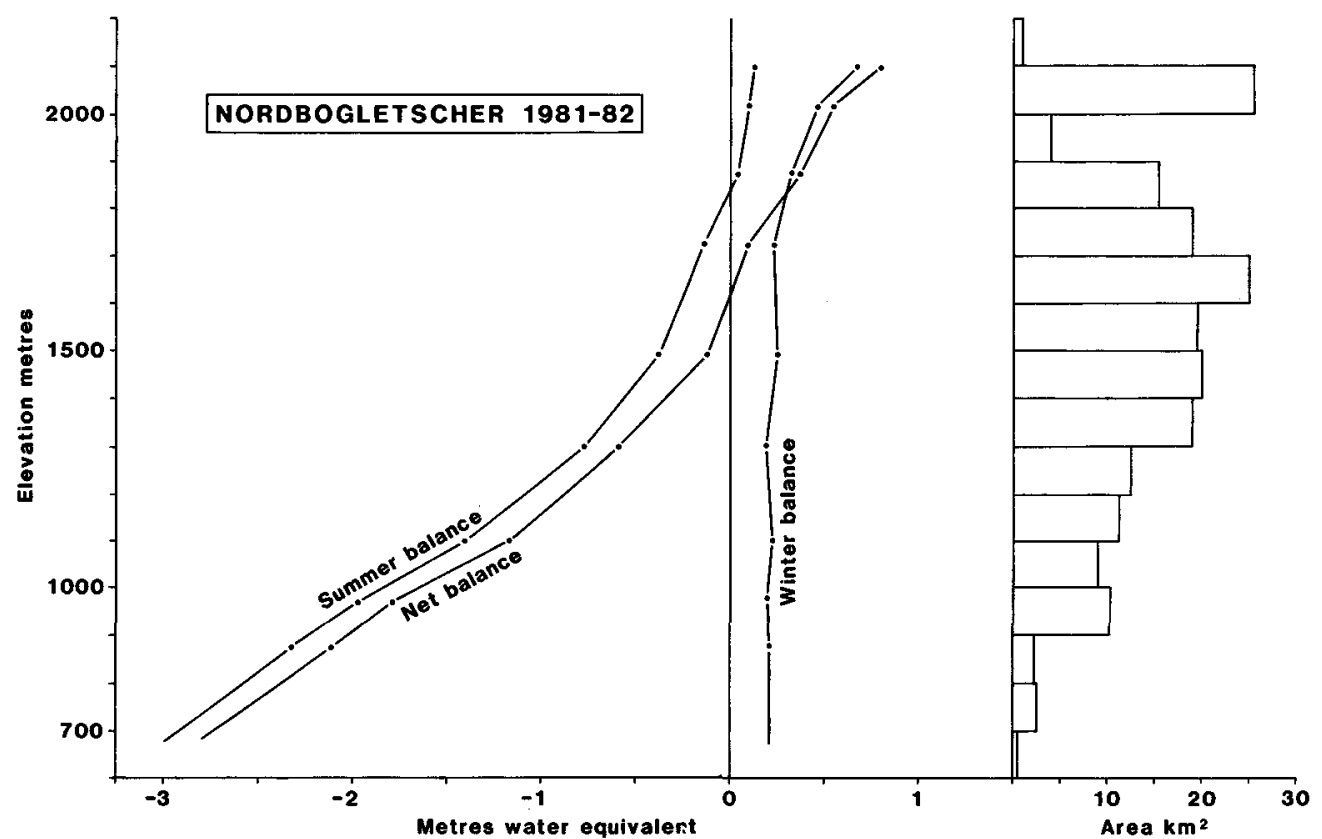

Fig. 49. Winter, summer and net balance in relation to elevation and glacier area distribution, Nordbogletscher 1981/82.

of bed-profiles on Nordbogletscher were recorded with a $300 \mathrm{MHz}$ ice-radar mounted in a helicopter. The data are being examined and the investigation will be continued next spring with radio-echo soundings from snow scooters. To supplement the results, digital analysis of Landsat imagery from where subglacial features can be traced has begun at the GGU (see Højmark Thomsen, this report).

It should be noted, however, that mass balance measurements over the topographic area of Nordbogletscher are important in connection with problems of ice dynamics. Nordbogletscher is in an advancing state (the glacier has advanced $600 \mathrm{~m}$ since 1947) and knowledge of the accumulation conditions is invaluable in any kind of model predicting glacier behaviour.

\section{Mass balance of local glaciers 1981/82}

The local glaciers studied in South Greenland in 1982 are well defined and better maps are available than elsewhere (both glaciers are mapped at 1:20000). They are thus suitable for mass balance studies.

Valhaltindegletscher occupies the northern slopes of Valhaltinde in Johan Dahl Land (fig. 48). The glacier with an area of $1.9 \mathrm{~km}^{2}$ is situated in the elevation range $1080 \mathrm{~m}$ to $1630 \mathrm{~m}$ above sea level.

The winter balance was measured on the 24 th of May. The glacier was entirely snowcovered, the snow temperature was still negative and there was no runoff. The total winter 
balance was calculated to be 0.52 million $\mathrm{m}^{3}$, i.e. a specific value of $0.28 \mathrm{~m}$ of water equivalent. The summer balance was measured on the 4th of September at the seven stakes inserted in the glacier. New snow $(30-60 \mathrm{~cm}$ ) already covered the whole glacier but is subtracted from the summer balance. The total summer balance is calculated to be -1.03 million $\mathrm{m}^{3}$ corresponding to a specific value of $-0.55 \mathrm{~m}$ of water equivalent. The net balance thus has a negative value of -0.51 million $\mathrm{m}^{3}$ and the equilibrium line is close to $1440 \mathrm{~m}$ above sea level.

Narssaq Bræ is a small cirque glacier north of Narssaq. Plans for using the meltwater for hydropower have been made by the Greenland Technical Organization (GTO, 1980). The glacier, with an area of $1.4 \mathrm{~km}^{2}$, is situated inside two cirque basins and has undergone considerable shrinkage since 1900 when its maximum size in historic time was reached.

The winter balance measurement on Narssaq Bræ on the 13 th of May was 1.33 million $\mathrm{m}^{3}$ while the summer balance measurement at the end of the ablation period was -1.80 million $\mathrm{m}^{3}$; the corresponding specific values are $0.93 \mathrm{~m}$ and $-1.26 \mathrm{~m}$ of water equivalent respectively. The net balance $1981 / 82$ on Narssaq Bræ thus shows a deficit of -0.47 million $\mathrm{m}^{3}$. The equilibrium line was situated at different elevations in the two basins occupied by the glacier but the mean value is $1150 \mathrm{~m}$ above sea level.

\section{Discussion of results}

Compared with last year's results (Clement, 1981, 1982) both the winter balance and the summer balance this year gave relatively small values on all three glaciers studied. The low
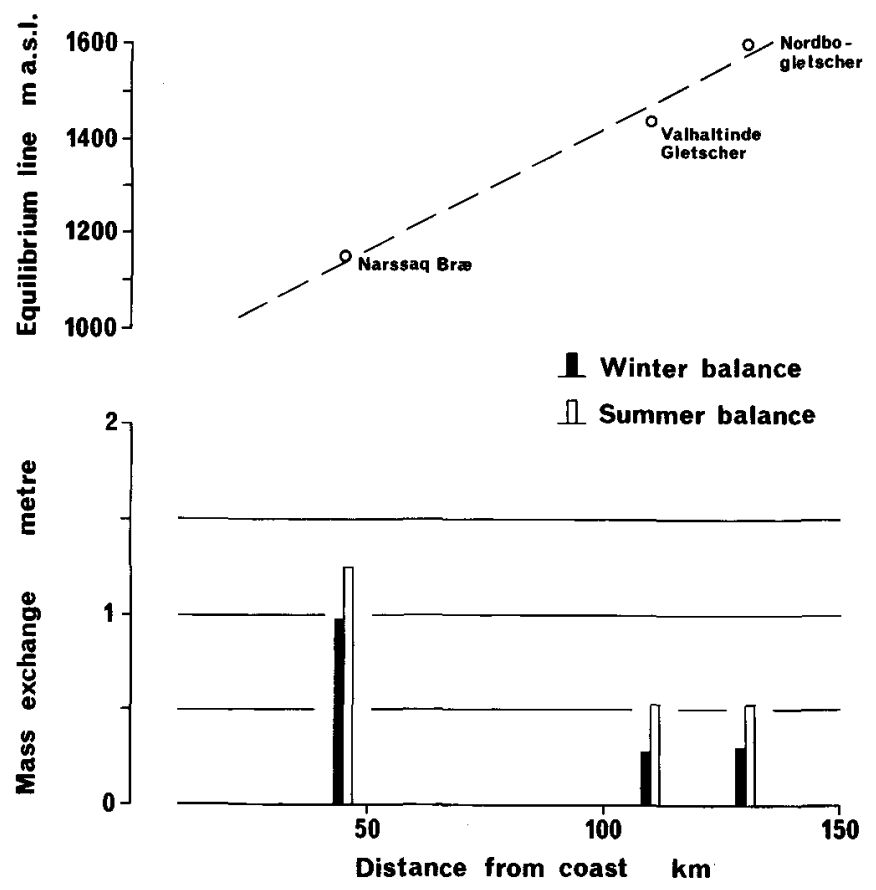

Fig. 50. Mass exchange on glaciers in South Greenland 1982. The glaciers are placed on a profile from the coast to the Inland Ice at approximately $61^{\circ} \mathrm{N}$. Also shown are the elevations of the equilibrium line. 
winter balance reflects the small amount of winter precipitation in South Greenland during the winter of 1981/82. In Narssarssuaq, the nearest meteorological station, the winter precipitation from October to April only amounts to $186 \mathrm{~mm}$. The summer was in addition short, cold and wet so the total mass exchange on the glaciers was low.

Comparing the three glaciers with each other (fig. 50) one finds that the summer balance in all cases exceeds the winter balance so the net balance was negative all over. As figure 50 further demonstrates, the mass exchange decreases as one goes from the coast region to the Inland Ice sector while the elevation of the equilibrium line increases. The conditions observed reflect the change of climate from a maritime one near the coast to more continental conditions in the interior of the country.

\section{References}

Braithwaite, R. J., Clement, P. \& Clausen, H. 1982: Inferences from a 19 m firn core, Nordbogletscher, South Greenland. Rapp. Grønlands geol. Unders. 110, 96-98.

Clement, P. 1981: Glaciological investigations in Johan Dahl Land 1980, South Greenland. Rapp. Grønlands geol. Unders. 105, 62-64.

Clement, P. 1982: Glaciological investigations in connection with hydropower, South Greenland. Rapp. Gronlands geol. Unders. 110, 91-95.

GTO 1980: Vandkraft omkring Tunugdliarfik. Rapp. Grønlands Tek. Org., 48 pp.

GTO 1982: Johan Dahl Land. Forundersøgelse. Vandkraft 1981. Rapp. Grønlands Tek. Org., 48 pp.

UNESCO 1970: Combined heat, ice and water balance at selected glacier basins. Tech. Pap. Hydrol., 5, $20 \mathrm{pp}$. 